\title{
INVESTIGATION ON THE MECHANICAL PROPERTIES OF RUBBERIZED STEEL FIBER CONCRETE
}

\author{
Ahmed Tareq NOAMAN ${ }^{\mathrm{a}, \mathrm{b}}$, Badorul Hisham ABU BAKAR ${ }^{\mathrm{a}}$, Hazizan MD. AKIL ${ }^{\mathrm{c}}$ \\ ${ }^{a}$ School of Civil Engineering, Engineering Campus, Universiti Sains Malaysia, \\ 14300 Nibong Tebal, Penang, Malaysia \\ ${ }^{b}$ Department of Dams and Water Resources Engineering, College of Engineering, \\ University of Anbar, Anbar, Iraq \\ 'School of Materials and Mineral Resources Engineering, Engineering Campus, \\ Universiti Sains Malaysia, 14300 Nibong Tebal, Penang, Malaysia
}

Received 01 March 2017; accepted 17 March 2017

\begin{abstract}
Researchers investigated the utilization of crumb rubber aggregate recycled from waste tire in concrete to solve the problem of discarded tire and to produce a green sustainable concrete. However, a reduction in the mechanical properties due to crumb rubber inclusion occurs. Steel fiber rubberized concrete used in this study to provide a balance between the strength loss and sustainable issue. An investigation on the mechanical properties of rubberized concrete combined with hooked - end steel fiber is presented. Rubberized concrete with different replacement ratios of crumb rubber was incorporated in plain and steel fiber concrete mixes via partial replacement of fine aggregate. Four replacement ratios $(17.5 \%, 20 \%, 22.5 \%$, and $25 \%$ ) were used to investigate the effect of the partial replacement of fine aggregate by crumb rubber on the mechanical properties of plain and steel fiber concrete. In both mixes, reduction in mechanical properties was observed to be proportionate with the increment of crumb rubber. Finally, a successful combination of steel fiber and crumb rubber was obtained due to improvement of strain capacity under flexural loading.
\end{abstract}

Keywords: recycling, rubberized concrete, steel fiber concrete, strain capacity, dynamic modulus of elasticity, sustainability.

\section{Introduction}

Recycling of waste products, such as worn out tires, plastic bags, paper, cartons, and soft drink cans, is one of the solutions for reducing the amount of waste on land. Discarded used tires on land results in environmental and economic problems (Issa, Salem 2013; Marques et al. 2013; Youssf et al. 2014) and occupy many public areas; such a manner of disposal is even illegal in certain countries (Siddique, Naik 2004). Furthermore, reducing the emission of $\mathrm{Co}_{2}$ produced from cement manufacturing by reducing the amount of cement used in constructions (Lee et al. 2016). Re- searchers have considered using recycled scrap tires as crumb rubber or rubber particles in concrete mixes to enhance certain concrete properties, such as ductility (Topçu, Avcular 1997; Zheng et al. 2008), toughness or energy absorption (Reda Taha et al. 2008; Khaloo et al. 2008; Atahan, Yücel 2012; Noaman et al. 2016), impact resistance (Al-Tayeb et al. 2013), fatigue (Liu et al. 2013), and many others (Sukontasukkul 2009). The use of steel fiber and crumb rubber has also been pointed out in many studies due to the desired properties of both materials when incorporated into concrete

Corresponding author:

A. T. Noaman E-mail:atn_en@yahoo.com 
mixes (Turatsinze et al. 2006; Liu et al. 2012; Nguyen et al. 2010). Mixing of steel fiber and rubber particles was investigated by Turatsinze et al. (2006) to evaluate the synergy between these materials in cement mortars. An improvement in cracking resistance caused by shrinkage and strain capacity under flexural loads was observed. In another study by Nguyen et al. (2010), the combination of rubber aggregate and fiber reinforcement in cementitious materials for repair works was investigated. The results indicated that there is an enhancement in the tensile capacity of rubberized steel fiber-reinforced mortars, which has a significant role in improving concrete durability via the combination of these two materials. The behaviour of rubberized steel fiber-reinforced concrete was investigated by Liu et al. (2012) where adding steel fiber at $0.5 \%$ by volume led to an increase in dynamic impact factor and dynamic compressive strength, furthermore, the metal steel fiber showed increase strength of rubberized concrete to impact loading using the split Hopkinson pressure bar. Guo et al. (2014a) investigated properties of steel fiber recycled concrete aggregates with various crumb rubber contents to investigate the effect of temperature on fracture properties of such concrete. Increasing fracture toughness and fracture energy was achieved up to a crumb rubber content of $8 \%$ by volume, which subsequently decreased their values. The steel fiber in this study improved both the ductility and resistance to cracks. In another study (2014b), the authors studied the influence of temperature change on the compressive properties of crumb rubber-reinforced steel fiber concrete with recycled aggregate. Although crumb rubber enhanced the toughness and resistance to explosive, spalling occurred at elevated temperatures, which subsequently decreased the compressive stress and modulus of elasticity (stiffness). Carroll and Helminger (2016) focused on the material properties of fiber-reinforced rubberized concrete and their study confirmed the feasibility of fiber reinforced concrete with crumb rubber inclusion. The results showed reduced values of the modulus of elasticity by $11 \%, 17 \%$, and $29 \%$ at coarse and fine rubber aggregate contents of $5 \%, 10 \%$, and $15 \%$ in fiber-reinforced mixes using rubber aggregate particles to replace total aggregate, respectively. Therefore, there is a need for more investigations on the benefit of interaction between steel fiber with moderate replacement ratios $(17.5 \%, 20 \%$, $22.5 \%$ and $25 \%$ ) of crumb rubber aggregate by replacement of sand on the hardened mechanical properties of the concrete. The selection of these ratios is to avoid high decrease in mechanical strength. The experiments consisted of the evaluation of static properties including cubes compressive strength, static modulus of elasticity, splitting tensile strength and flexural strength of beams and the measuring of the ultrasonic pulse velocity using non-destructive techniques and estimation of dynamic modulus of elasticity. This study builds upon previous works and provides a background for upcoming researches on this type of concrete. Furthermore, a potential solution of the disposal of discarded tires problem could be realized via the utilization of waste materials into concrete towards a cleaner and sustainable construction.

\section{Experimental work}

\subsection{Materials}

The ingredients of the concrete mix used in this study included of locally manufactured ordinary Portland cement) Type 1) with specific gravity of 3.15. Natural fine sand from river used as fine aggregate with specific gravity of 2.64 and particle size distribution is shown in Figure 1. Crushed stone used as coarse aggregate with specific gravity of 2.65 and has uniform size (10-14) $\mathrm{mm}$. Bundled hooked ended steel fiber of 80 (aspect ratio) and having the diameter of $0.75 \mathrm{~mm}$, specific gravity 7.85 and tensile strength $1050 \mathrm{MPa}$ added as $0.5 \%$ as a volume fraction. Crumb rubber aggregate produced locally by recycling of discarded worn-out tires of an average size of (1-2) $\mathrm{mm}$ with a relative density of 0.73 added to concrete as a replace-

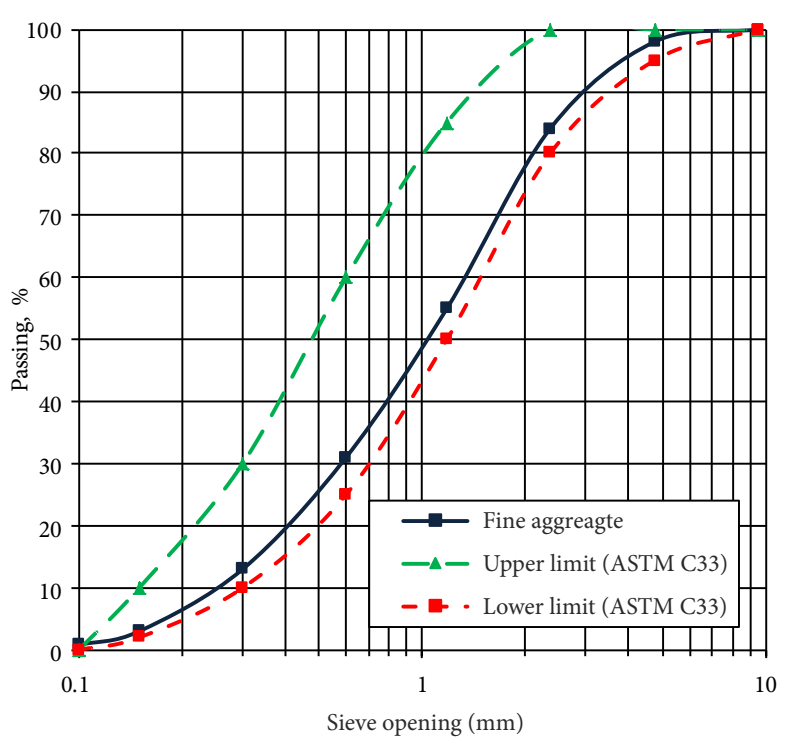

Fig. 1. Particle size distribution of fine aggregate (sand) 
ment of fine aggregate volume at different ratios $17.5 \%$, $20 \%, 22.5 \%$ and $25 \%$. Commercially available water reducer (superplasticizer) with advanced polycarboxylic ether (PCE) based (Glenium ACE 309) and the reducing rate of $(30 \%)$ of water used as an admixture to fulfil the required slump for the steel fiber concrete mixes added with a constant dosage by $0.3 \%$ of cement weight. The specific gravity and $\mathrm{PH}$ for this chemical admixture are 1.06 and 4-7, respectively. The crumb rubber and steel fiber used in this study are shown in Figure 2 .
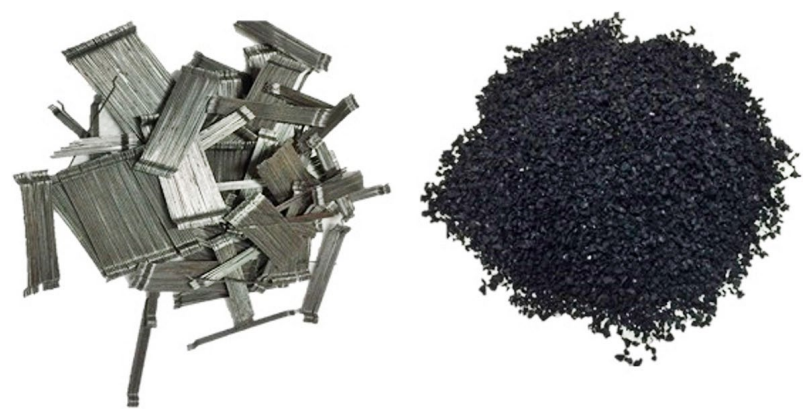

Fig. 2. Hooked end steel fiber and crumb rubber aggregate used in this study

\subsection{Preparation of specimens}

In this study, the total number of specimens prepared was 120. Each mix has twelve samples: three cubes with $100 \mathrm{~mm}$ side were used for density and ultrasonic pulse velocity (UPV) measurements. For compression test and modulus of elasticity, three cylinders having dimensions of $(200 \times 100) \mathrm{mm}$ (Height $\times$ Diameter $)$ were prepared. To evaluate the split - tensile strength of concrete, another three cylinders having dimensions of $(165 \times 100) \mathrm{mm}$ (Height $\times$ Diameter $)$ were used. For the flexural test, prismatic specimens having dimensions of $(350 \times 100 \times 100) \mathrm{mm}$ (Length $\times$ Width $\times$ Depth $)$ were prepared in accordance to ASTM C192 (2013). Initially, the aggregate and crumb rubber were mixed and blended with cement in dry mixing for 2 minutes. Half of the additional water was then added, and the mixture was blended for another 2 minute. The remaining water was added with superplasticizer and pour into the rotating mixer. The steel fiber was spread into the mixture and continues mixing for 4 minutes. After casting, the specimens were poured into different iron molds and then covered with a plastic sheet for 24 hours at room temperature. Then, the samples were removed from the molds and stored in a water basin for curing at $23 \pm 2{ }^{\circ} \mathrm{C}$. The curing continued until 28 days to conduct the tests of the prepared specimens. The mixing proportions are listed in Table 1.

\subsection{Properties determination}

Three cylinders from each mix were tested to determine the results of the compressive strength and the static modulus of elasticity as an average of three points. The test was conducted herein to be in accordance with requirements of ASTM C469 (2014) with the loading rate selected in this study $(0.3 \mathrm{MPa} / \mathrm{sec})$. The splitting tensile strength was carried out using loading rate $0.9 \mathrm{MPa} / \mathrm{min}$ according to ASTM C496 (2011) The non - destructive tests include (density and UPV) was carried out according to BS 1881:114 (1983) and ASTM C597 (2009), respectively. Finally, flexural test was conducted to obtain the stress-deflection curves

Table 1. Mixing proportions (unit weight $\mathrm{kg} / \mathrm{m}^{3}$ )

\begin{tabular}{|c|c|c|c|c|c|c|c|}
\hline Symbol & Cement & $\begin{array}{c}\text { Coarse } \\
\text { aggregate }\end{array}$ & $\begin{array}{c}\text { Fine } \\
\text { aggregate }\end{array}$ & $\begin{array}{c}\text { Hooked end } \\
\text { steel fiber }\end{array}$ & $\begin{array}{c}\text { Rubber } \\
\text { aggregate }\end{array}$ & Water reducer & W/C \\
\hline PC & 430 & 907 & 814 & - & - & - & 0.47 \\
\hline SFC & 430 & 907 & 814 & 39.2 & - & 1.5 & 0.47 \\
\hline CRC17.5 & 430 & 907 & 670 & - & 39.5 & - & 0.47 \\
\hline CRC20 & 430 & 907 & 649 & - & 45.3 & - & 0.47 \\
\hline CRC22.5 & 430 & 907 & 630 & - & 50.3 & - & 0.47 \\
\hline CRC25 & 430 & 907 & 610 & - & 56.2 & - & 0.47 \\
\hline SFCRC17.5 & 430 & 907 & 670 & 39.2 & 39.5 & 1.5 & 0.47 \\
\hline SFCRC20 & 430 & 907 & 649 & 39.2 & 45.3 & 1.5 & 0.47 \\
\hline SFCRC22.5 & 430 & 907 & 630 & 39.2 & 50.3 & 1.5 & 0.47 \\
\hline SFCRC25 & 430 & 907 & 610 & 39.2 & 56.2 & 1.5 & 0.47 \\
\hline
\end{tabular}

Notes: PC - plain concrete; SFC - steel fiber concrete; CRC ( ) - rubberized concrete with replacement ratio ( ); SFCRC ( ) - steel fiber rubberized concrete with replacement ratio ( ). 
and the specimens were subjected to a third span loading (span length $300 \mathrm{~mm}$ ) as suggested by ASTM C78 (2010) and ASTM C1609 (2012). In this test, the loading rate was $0.15 \mathrm{~mm} / \mathrm{min}$ using a hydraulic testing machine (Shimadzu $100 \mathrm{KN}$ ), which has a built-in data acquisition and computerized analysis system to save the measured data obtained during the test. The tests setup is shown in Figure 3.

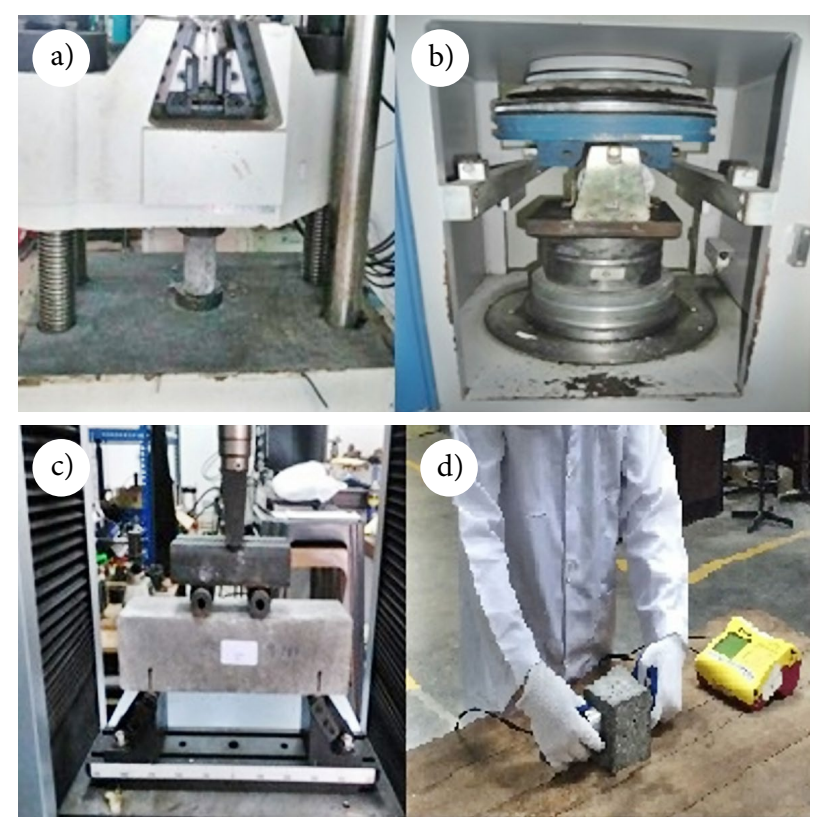

Fig. 3. Tests setup: (a) compressive strength; (b) splitting tesile strength; (c) flexural strength; and (d) Ultasonic Pulse Velocity

\section{Results and discussion}

\subsection{Density}

The results of density determination of concrete cubes are shown in Figure 4. The increase in the crumb rubber aggregate substitution by replacing of river sand decreased values of density of plain concrete. The reduction in density was $7 \%$ at $25 \%$ volumetric replacement of sand aggregate by recycled crumb rubber. The reduction may be attributed to density of total fine aggregate in which crumb rubber have a lower than that of river sand. Similar trend was observed also for steel fiber concrete when recycled rubber tires added to the concrete. The rate of decrease of densities was $4 \%$ to $7 \%$ for steel fiber rubberized concrete. However, it was recommended a smaller crumb rubber particle size to provide a sufficient air entertainment and this leads to a considerable protection against freeze - thaw effects (Richardson et al. 2016). Generally, in the presence of

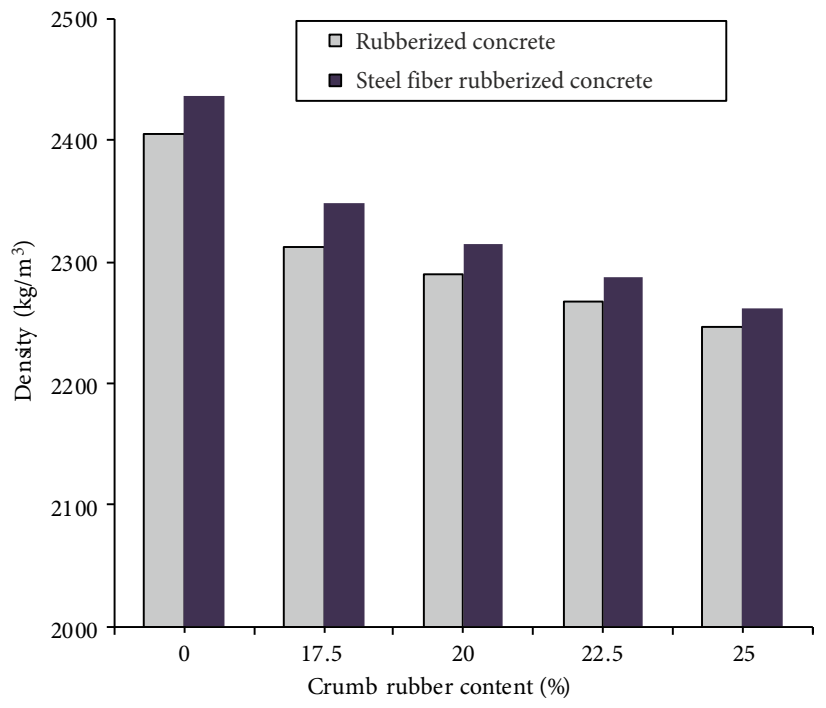

Fig. 4. Density of different concrete mixtures in this study

steel fiber, a balance between its volumetric ratio and crumb rubber contents regardless of the rubber particle size was observed in this study.

\subsection{Compressive strength}

The results were determined in this study from the compressive stress test at the age of 28 days are shown in Figure 5. The plain concrete grade is $40 \mathrm{MPa}$. As shown in Figure 5, adding rubber aggregate particles to ordinary and steel fiber concrete led to a decline in the compressive strength values. The maximum reduction was $46 \%$ for the replacement of $25 \%$ of fine aggregate by crumb rubber in plain concrete. It was noticed in Figure 5, that, the rate of reduction of compressive strength increased at a ratios of $22.5 \%$ and $25 \%$ more than other replacement ratios. This is indicating that the reduction in the compressive strength of a concrete cube becomes greater when crumb rubber ratio more than $20 \%$. However, the maximum reduction was $30 \%$ for the same replacement ratio in plain concrete and $31 \%$ when the particles sand aggregate was replaced with recycled rubber particles in steel fiber concrete.

In a previous study (Ghaly, Cahill 2005) related to rubberized concrete with crumb rubber size of 1 $\mathrm{mm}$ to $2 \mathrm{~mm}$ and $\mathrm{W} / \mathrm{C}$ ratio $=0.47$ exhibited a decrease in compressive strength $(26 \%, 48 \%$, and $59 \%)$ for the replacement of natural fine sand using crumb rubber aggregate with ratios $(5 \%, 10 \%$, and $15 \%)$, respectively. Compressive strength reduction of rubberized concrete was attributed by many studies to crumb rubber particles, which function as voids with stiff- 


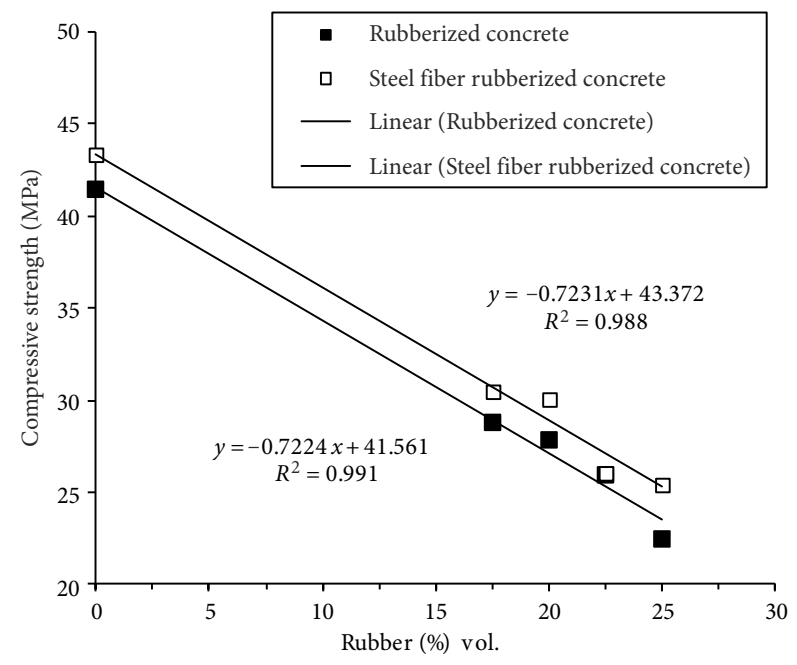

\begin{tabular}{|c|c|c|c|}
\hline Mix & $\begin{array}{c}\text { Standard } \\
\text { Deviation (Mean) }\end{array}$ & Mix & $\begin{array}{c}\text { Standard } \\
\text { Deviation (Mean) }\end{array}$ \\
\hline PC & 0.89 & SFC & 0.69 \\
\hline CRC17.5 & 0.96 & SFCRC17.5 & 1.06 \\
\hline CRC20 & 1.23 & SFCRC20 & 0.79 \\
\hline CRC22.5 & 0.98 & SFCRC22.5 & 1.18 \\
\hline CRC25 & 1.11 & SFCRC25 & 0.85 \\
\hline
\end{tabular}

Fig. 5. Effect of crumb rubber ratio as a replacement of fine aggregate on compressive strength of plain and steel fiber concrete

ness lower than that of fine aggregate particles, and to the porous property of crumb rubber (Fattuhi, Clark 1996; Ho et al. 2008). Other reasons include a variance in the modulus of elasticity between rubbers and cement paste as well as defects in the zone rounded the aggregate (Najim, Hall 2010). Replacements with small contents of crumb rubber aggregate in steel fiber reinforced concrete slightly decreases compressive strength compared with plain concrete. On the other hand, adding steel fiber to concrete mixes is required to improve toughness and tensile strength instead of compressive properties (Guo et al. 2014a). Figure 6 shows the correlation between compressive strength and density. An increase in the density increases the compressive strength. An empirical relationships where also obtained for both plain and steel fiber reinforced concrete with the content of crumb rubber is shown in Figure 6.

\subsection{Static modulus of elasticity}

The measured values of the static modulus of elasticity $E_{S}$ for the plain and steel fiber concrete with different percentages of rubber ratios is shown in Figure 7. Incorporating crumb rubber aggregate reclaimed from discarded tires reduced $E_{S}$ for both plain and steel fiber concrete. For rubber concrete without steel fiber, the

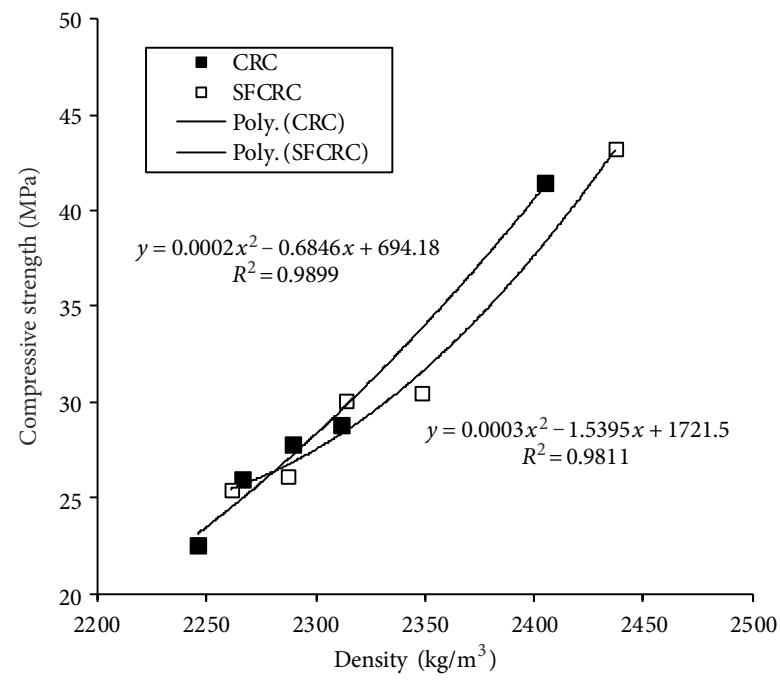

Fig. 6. The relationship between density and compressive strength of CRC and SFCRC

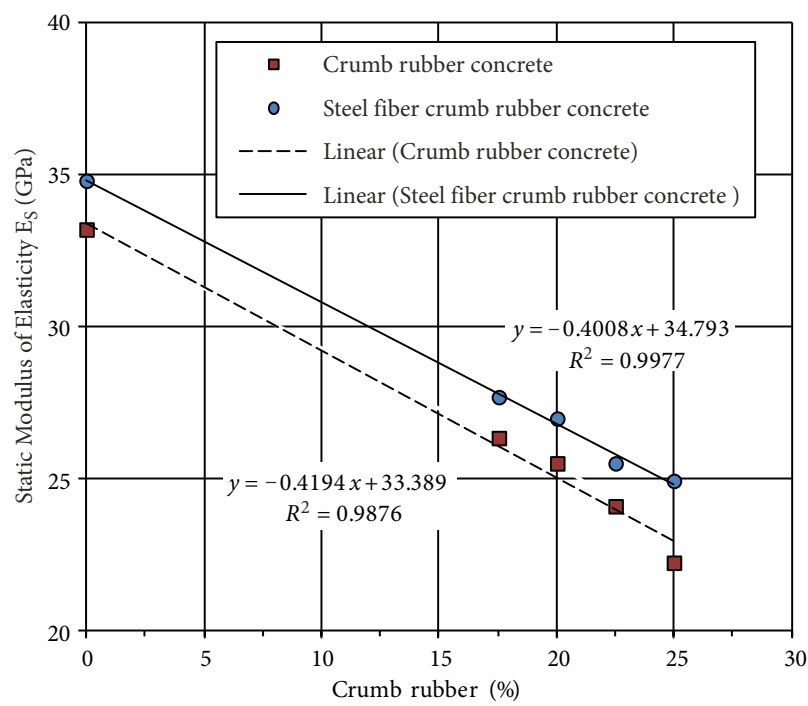

\begin{tabular}{|c|c|c|c|}
\hline Mix & $\begin{array}{c}\text { Standard } \\
\text { Deviation (Mean) }\end{array}$ & Mix & $\begin{array}{c}\text { Standard } \\
\text { Deviation (Mean) }\end{array}$ \\
\hline PC & 1.21 & SFC & 0.85 \\
\hline CRC17.5 & 0.88 & SFCRC17.5 & 0.96 \\
\hline CRC20 & 1.01 & SFCRC20 & 1.29 \\
\hline CRC22.5 & 0.74 & SFCRC22.5 & 1.20 \\
\hline CRC25 & 0.80 & SFCRC25 & 0.95 \\
\hline
\end{tabular}

Fig. 7. Effect of crumb rubber content on static modulus of elasticity of rubberized concrete

reduction of the static modulus was $33 \%$ with $25 \%$ crumb rubber. For rubberized concrete, the average reduction value of $E_{S}$ was $29 \%$. The modulus of elasticity is $33.2 \mathrm{GPa}$ for ordinary concrete, whereas that fibrous concrete is $34.8 \mathrm{GPa}$. For steel fiber rubberized concrete, the values obtained at replacements ratios of $17.5 \%, 20 \%$, and $22.5 \%$ resulted in $84 \%, 82 \%$, and $77 \%$, respectively, of the modulus of elasticity of reference 


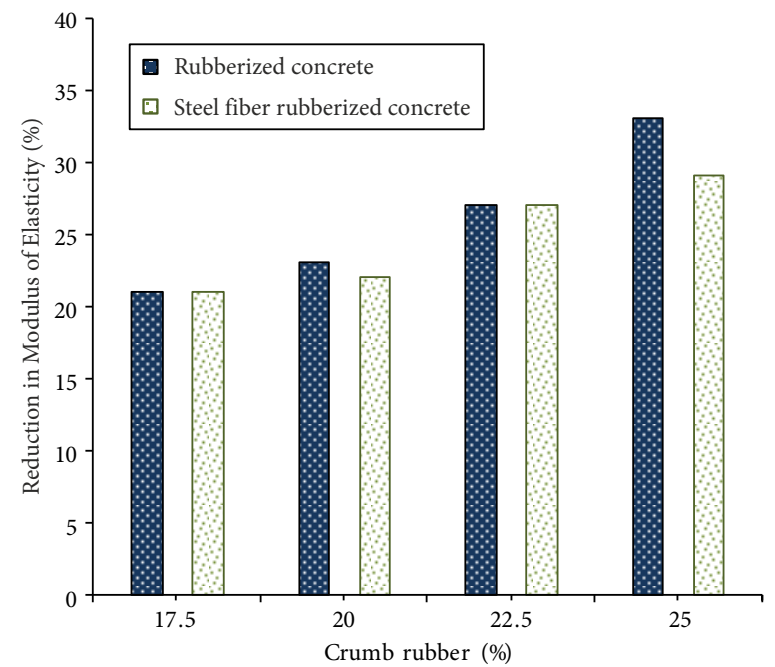

Fig. 8. Reduction percentage in the elastic modulus with respect to crumb rubber replacement ratios

concrete as seen in Figure 8. In this study, steel fiber was used in the plain mix to improve tensile properties compared with compressive strength or static modulus of elasticity as well. The results of the elastic modulus under static load obtained through experimental work exhibited a decrease in it is value with the increase of crumb rubber content for both plain and steel fiber concrete. Such decrease was expected due to the relationship between compressive strength and the static modulus. Also, $E_{S}$ of any type of concrete is affected by the modulus of elasticity of the aggregate as well as it is the volumetric percentage in the bulk matrix of the concrete (Ho et al. 2012; Hobbs 1971). Further works are needed to study additional factors influence the static modulus of elasticity such as crumb rubber particle size and steel fiber ratio or treatment of crumb rubber to improve bonding with cement paste and natural aggregate for steel fiber rubberized concrete.

\subsection{Splitting tensile strength}

Similar to compressive strength and the modulus of elasticity, the partial replacement of sand with crumb rubber particles reduced the values of tensile strength obtained for plain and steel fiber concrete. Splitting tensile strength was reduced by $21 \%$ to $31 \%$ when crumb rubber aggregate included into plain reference concrete mix and by $23 \%$ to $32 \%$ when crumb rubber substituted sand in steel fiber concrete. The data obtained are shown in Figure 9. With change of rubber content, the decrease in tensile strength increased for both plain and steel fiber concrete. This reduction

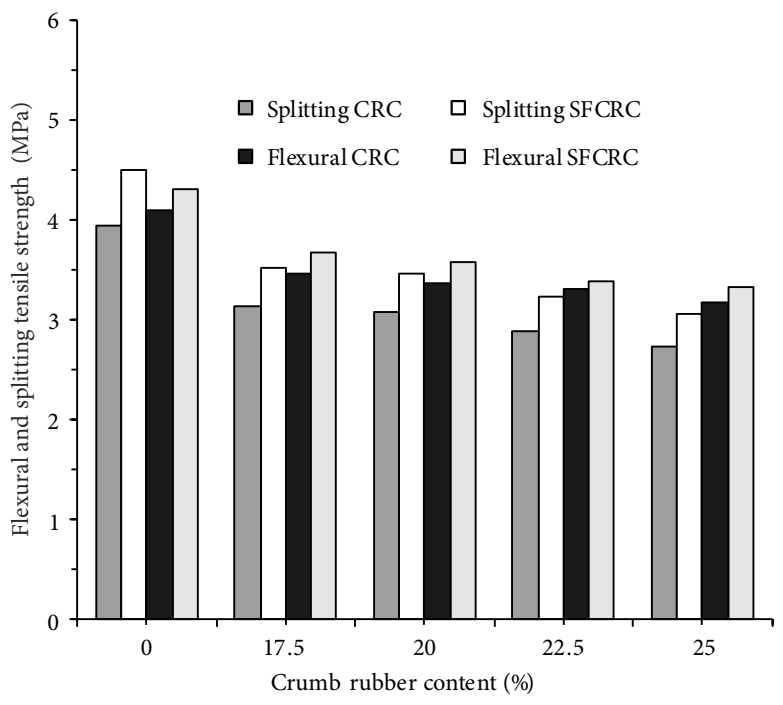

Fig. 9. Flexural and splitting tensile strength with respect to replacement ratio of crumb rubber for plain and steel fiber concrete

was clearly lower than the decrease in compressive strength results obtained in this study. This finding is associated with many factors that had been discussed earlier (Albano et al. 2005). The results for steel fiber rubberized concrete revealed that the decrease was lower than those for crumb rubber concrete. Adding steel fiber to plain concrete by $0.5 \%$ of the volume fraction showed an improvement of $\sim 14 \%$. Earlier studies have reported development in the results of splitting tensile strength of ordinary concrete by using hookedend steel fiber with respect to volume fraction and aspect ratio (Thomas, Ramaswamy 2007; Yazıcı et al. 2007). Small fractions of steel fiber had minimal effect on tensile strength (Ibrahim, Che Bakar 2011). The mechanical properties obtained by incorporating steel fiber with a volume fraction of $0.5 \%$ and crumb rubber have not been investigated previously. However, incorporating steel fiber with crumb rubber into concrete tended to limit the effect of rubber particles to reduce tensile strength (Nguyen et al. 2010), which improved strength compared with both plain and rubberized concrete mixes. Figure 10 shows a positive correlation between results of the splitting tensile strength measured in this study and values of compressive strength for both crumb rubber concrete (CRC) and steel fiber rubberized concrete (SFCRC). To predict splitting tensile strength of SFCRC with different replacement ratios, an empirical formula was proposed as show in Figure 10. 


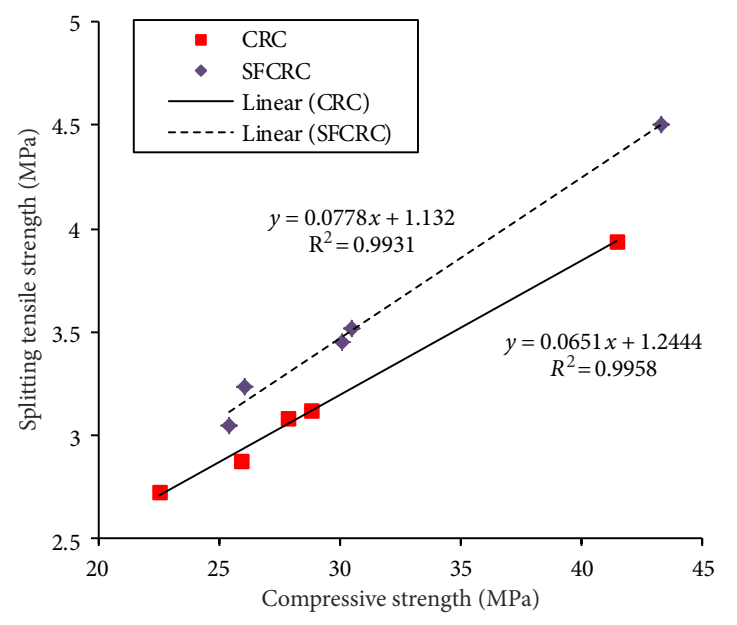

Fig. 10. Relationship between compressive strength and tensile strength in this study

\subsection{Flexural strength}

The results of the four-point load bending test are shown in Figure 9, also. As expected, the replacement of sand by crumb rubber aggregate reduced the flexural strength of both concrete mixes, namely, plain and steel fiber. The maximum stress measured was for steel fiber concrete mix where an increase of approximately $7 \%$ was noticeable. The peak flexure stress measured during this test reduced by the increase in the proportion of crumb rubber replacement. However, the decrease in crumb rubber flexural stress led to a reduction of approximately $22.7 \%$ for a replacement ratio of $25 \%$. Another reduction in stress was obtained for steel fiber concrete with rubber crumb substitution. The values obtained with crumb rubber replacement were less than the steel fiber values and greater than the stress values for crumb rubber concrete. The reduction in flexural stress was $14.8 \%, 16.9 \%, 21.4 \%$ and $22.5 \%$ at $17.5 \%, 20 \%, 22.5 \%$ and $25 \%$ replacement ratios of sand with crumb rubber aggregate $(1-2) \mathrm{mm}$. These values generally remained less than the flexural stress for the plain concrete mix (4.1 MPa). The reduction in flexural strength was attributed to various reasons that affect flexure behaviour and compressive strength. The defect in bonding between rubber particles and aggregate (Khatib, Bayomy 1999) or the cement paste (Onuaguluchi, Panesar 2014), as well as the negligible value for tensile strength of plain concrete, could not provide appropriate resistance to stresses that caused early failure before the ultimate strength capacity (Ganjian et al. 2009).

Unlike stress values, the results of the strain capacity obtained in this study from load deflection curves presented an increase in these values with respect to partial replacement of sand using crumb rubber particles. The strain capacity was considered as the deflection measured at the maximum load according to Turatsinze et al. (2006) and Najim and Hall (2012). As shown in Figure 11, these values increased with respect to the replacement ratios sand by crumb rubber of $17.5 \%$ and $20 \%$. Beyond $20 \%$ rubber content, values of the strain capacity (maximum deflection) decreased but still higher than the references mix. The improvement of strain capacity of plain concrete with crumb rubber inclusion was significantly higher than that of steel fiber concrete at the same replacement ratios of crumb rubber added. This is due to limited effect of crumb rubber aggregate on improving ductility of concrete with rationally higher strength than the reference or lower strength mixes. However, the tendency of crumb rubber to increase straining capacity could be observed in this study. Similar trend was observed by Lijuan et al. (2014) indicating the tendency of rubber aggregate to improve the strain capacity of concrete and modifying the deformability and toughness at appropriate rubber particles size and content.

The rate of increase of strain capacity was 39\%, $42 \%, 40 \%$ and $36 \%$ at $17.5 \%, 20 \%, 22.5 \%$, and $25 \%$ rubber content. While it was $30 \%, 32 \%, 29 \%$ and $26 \%$ at the same replacement ratios, respectively for steel fiber rubberized mixes. A combined effect can be observed here with the partial inclusion of rubber aggregate from waste tires and hooked end steel fiber in ordinary mixes. For the replacement ratio of $17.5 \%$,

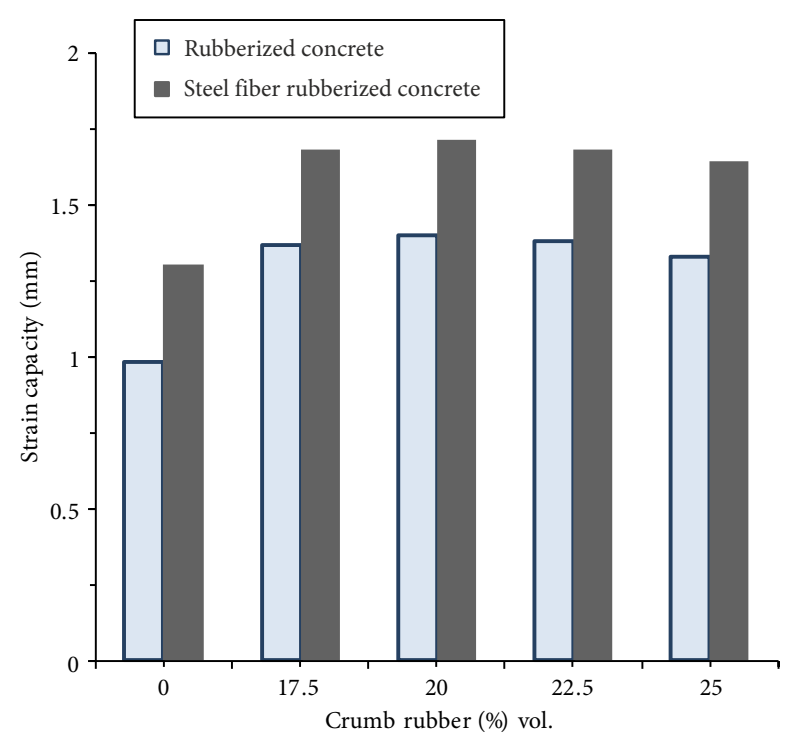

Fig. 11. Strain capacity with respect to crumb rubber content in plain and steel fiber concrete 
the strain capacity of rubberized concrete was higher than that of the steel fiber mix by about $5 \%$. On the other hand, the maximum deflection for the SFCRC17.5 mix was superior to that for rubberized concrete incorporated with $25 \%$ crumb rubber. Turatsinze et al. (2006) reported an increase in the strain capacity of rubberized mortars containing shredded rubber tires and metal fiber. The straining capacity was $150 \%$ higher than the reference cementitious composite with the inclusion of rubber aggregate at 30\% replacement of total aggregate volume. Furthermore, at the same crumb rubber particles content and with combination of strait steel wire fibers of $40 \mathrm{~kg}$ in cubic meter content an enhancement of straining capacity was $162.5 \%$.

The increase in strain capacity for hybrid rubberized concrete was also observed by Al-Tayeb et al. (2013); with an increase in fracture energy under static loading was determined up to a replacement ratio $20 \%$ of fine crumb rubber aggregate. Thus, the results observed in this study are consistent with earlier investigation. However, replacement ratio of $22.5 \%$ and $25 \%$ was found in this study affected the strain capacity results negatively. Many previous studies also recommended the optimal rubber content to not to be more than 20\% (Khatib, Bayomy 1999) or 25\% (Güneyisi et al. 2004). The reduction beyond optimum rubber ratio was attributed to the distribution of the rubber aggregate in the concrete matrix while further increase in it is content leads to a weakness in the rubber to cement matrix link that causes decrease in the strength again (Shen et al. 2013).

The increase in the strain capacity caused by incorporating crumb rubber is explained in this paper by considering the presence of steel fiber, which causes crumb rubber to have a cumulative effect on concrete mixes. With partial replacement of natural sand aggregate by recycled crumb rubber, the rubberized concrete becoming more ductile than the conventional concrete. The role of rubber particles is to impede the occurrence of microcracks before or near the peak loading stage (Najim, Hall 2012). The presence of rubber particles caused a relaxation in the stress concentration that developed at the interfacial transition zone between aggregate and cement paste produced by arresting the crack tip (Turatsinze et al. 2006). Thus, strain capacity was improved, and this gain absorbed additional energy. A cumulative effect caused by the presence of hooked-end steel fiber with long aspect ratio was also observed. Steel fibers increased strength and ductility compared with plain concrete as observed previously in hybrid fiber rubberized mixes (Park et al. 2015). Also, fiber bridging was induced, which improved the toughness and ductility of rubberized concrete when subjected to flexure loads. Figure 12 illustrates a schematic simulation of the bridging effect of rubber aggregate and hooked ended steel fiber. Where the crumb rubber aggregate particles are responsible for the arresting of the micro - cracks generated in the cement matrix and affect as energy absorbers, due to their elastic property (Afshinnia, Poursaee 2015). While for the higher level of crack propagation, the hook end steel fiber provided the sufficient bridging of the cracks and this effect continue until failure. This argument was also presented previously by Rambo et al. (2014) to illustrate the effect of fiber hybridization on fracture behaviour of self-consolidating concrete.

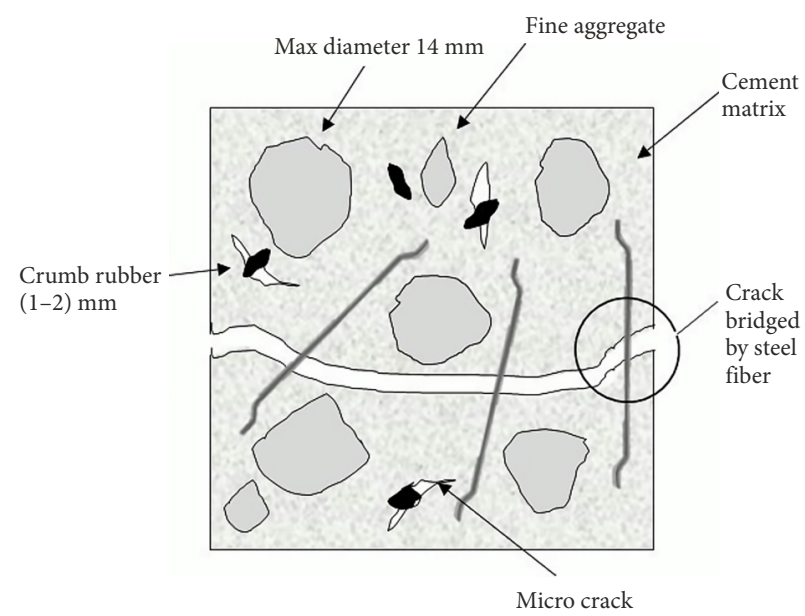

Fig. 12. Simulation of the effect of steel fiber and crumb rubber on crack bridging in cement paste in accordance to the

fibre hybridization concept presented by Rambo et al.

SEM observation of steel fiber is shown in Figure 13(a). The steel fiber provides an adequate bonding with the cement paste, while, Figure 13(b) shows poor attachment between crumb rubber aggregate and the cementitious paste by the presence of a groove along rubber boundaries. Thus, could explain the enhancement in the mechanical properties by the inclusion of steel fiber into rubberized mix and the reduction into mechanical properties capacity by the inclusion of crumb rubber.

\subsection{Ultrasonic pulse velocity}

While many studies have been conducted on the determination of the ultrasonic - pulse velocity (UPV) of rubberized concrete (Khaloo et al. 2008; Najim, 

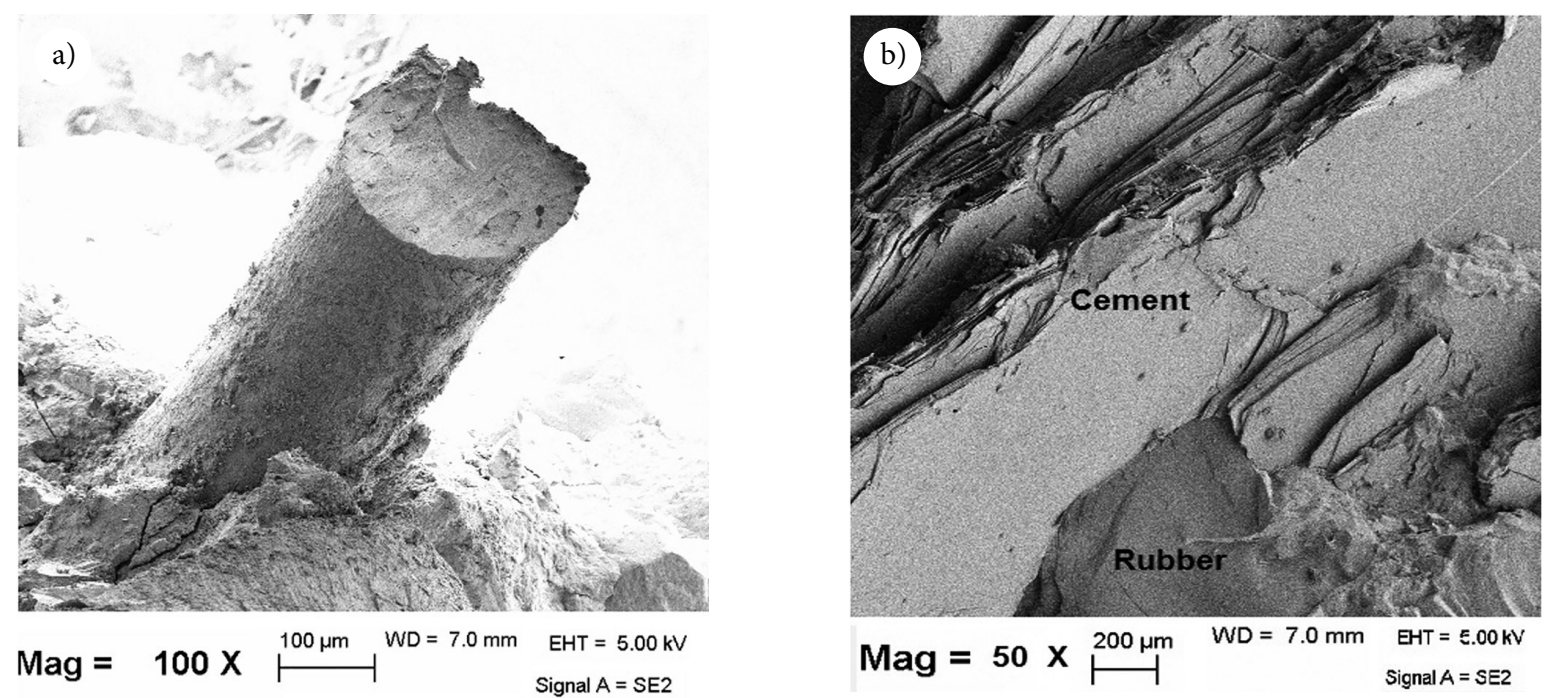

Fig. 13. Microstructure of rubberized concrete (a) steel fiber within the cement matrix; (b) rubber to concrete inteface

Hall 2012; Albano et al. 2005; Marie 2016; Mohammed et al. 2011), thus far, no such study was carried out determine the UPV of steel fiber reinforced rubberized concrete. The effect of rubber content on UPV is shown in Figure 14 at age of 28 days. It can be concluded that the UPV values decrease with an increase in the recycled rubber aggregate ratios from $17.5 \%$ to $25 \%$. The reduction in the UPV was $24 \%$ at $25 \%$ rubber content. At the same time, this trend of reduction

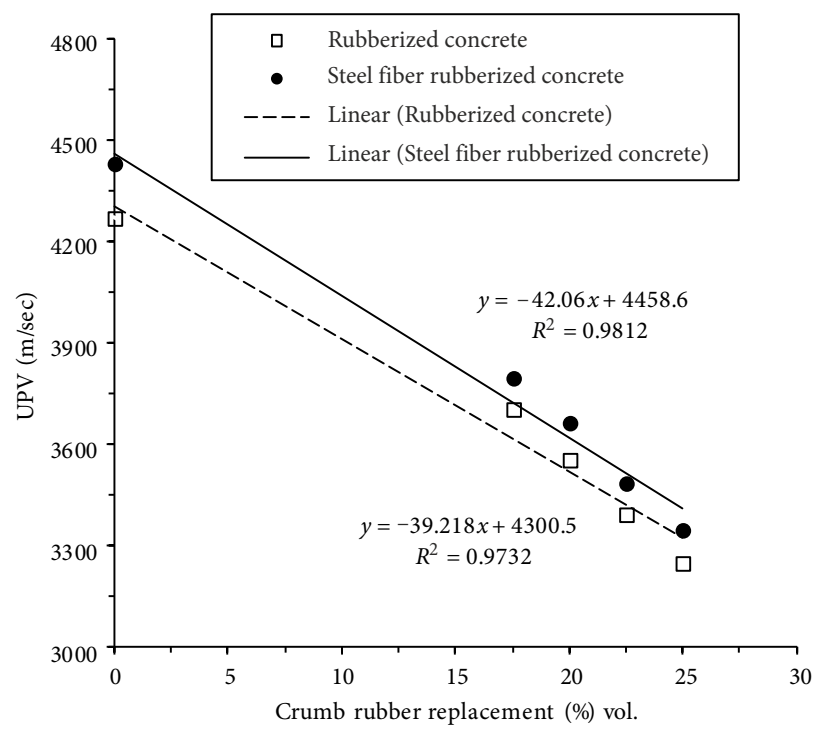

\begin{tabular}{|c|c|c|c|}
\hline Mix & $\begin{array}{c}\text { Standard Deviation } \\
(\text { Mean })\end{array}$ & Mix & $\begin{array}{c}\text { Standard Deviation } \\
\text { (Mean) }\end{array}$ \\
\hline PC & 0.89 & SFC & 0.69 \\
\hline CRC17.5 & 0.96 & SFCRC17.5 & 1.06 \\
\hline CRC20 & 1.23 & SFCRC20 & 0.79 \\
\hline CRC22.5 & 0.98 & SFCRC22.5 & 1.18 \\
\hline CRC25 & 1.11 & SFCRC25 & 0.85 \\
\hline
\end{tabular}

Fig. 14. Ultrasonic pulse velcotiy of CRC and SFCRC with different rubber content was observed for SFCRC with different replacement ratios. However, higher values of UPV for steel fiber rubberized concrete mixture were observed compared to non-fibrous rubberized mixtures due to inclusion of steel fiber in this study. For instance, UPV for SFCRC22.5 was $3482 \mathrm{~m} / \mathrm{sec}$ while it was $3393 \mathrm{~m} / \mathrm{sec}$ for CRC22.5 (Table 2). This is attributed to reduction in the UPV due to crumb rubber inclusion into normal concrete. This reduction in UPV is mainly due to increase of entrapped air by crumb rubber aggregate, which can increase via the percentage of crumb rubber replacement, decreasing UPV (Mohammed et al. 2011). Moreover, generation of micro cracks in the concrete matrix via the replacement of fine aggregate compared to the soft crumb rubber aggregate (Marie, 2016). The velocities of the ultrasonic waves generally decrease considerably when the crumb rubber aggregate ratio increases.

According to Solis-Carcaño and Moreno classification (2008), based on UPV measurements the concrete can be classified into excellent, good, questionable, poor, and very poor. For rubberized concrete mixes in this study, CRC17.5, SFCRC17.5 and SFCRC20 can be considered as (good) according to this classification (UPV greater than $3660 \mathrm{~m} / \mathrm{sec}$ ).

Table 2. Values of UPV of concrete mixes $(\mathrm{m} / \mathrm{sec})$

\begin{tabular}{|l|c|c|c|c|c|}
\hline $\begin{array}{l}\text { Type of } \\
\text { concrete }\end{array}$ & $0 \%$ & $17.5 \%$ & $20 \%$ & $22.5 \%$ & $25 \%$ \\
\hline $\begin{array}{l}\text { Plain } \\
\text { concrete }\end{array}$ & 4268 & 3705 & 3555 & 3393 & 3248 \\
\hline $\begin{array}{l}\text { Steel fiber } \\
\text { concrete }\end{array}$ & 4430 & 3797 & 3664 & 3482 & 3345 \\
\hline
\end{tabular}


Another classification for rubberized concrete based on UPV was presented recently by Marie (2016). The rubberized concrete classified to three zones; A, B and C. For crumb rubber with content $0-25 \%$, it can be classified within zone $\mathrm{A}$, in which can considered suitable for structural applications, where a reduction in the UPV less than 50\%. For steel fiber rubberized concrete in this study, it could be considered within zone A. However, SFCRC20 falls in Zone A (3.66$4.58 \mathrm{~km} / \mathrm{sec}$ ) which could be suggested as a limited ratio of rubber aggregate incorporated in steel fiber reinforced concrete. For fibrous concrete, the inclusion of crumb rubber aggregate improved its capacity to absorb the transit velocity, which can be considered as a good material for sound absorption and with suitable strength to resist structural loading. Further investigations related to the non - destructive testing of rubberized steel fiber concrete still needed. However, a linear relationship between UPV and density is existed for steel fiber rubberized concrete in this study as shown in Figure 15. With the increase in density, the UPV increased for steel fiber rubberized concrete. This trend was observed also for rubberized concrete considered in this study.

\subsection{Dynamic modulus of elasticity}

The dynamic modulus of elasticity $E_{D}$ was calculated in this study using the equation presented by Uygunoğlu and Topçu (2010). The dynamic modulus of elasticity $E_{D}(\mathrm{GPa})$ can be estimated as:

$$
E_{D}=\left[\frac{V^{2}}{g} \times \rho\right] \times 10^{-2},
$$

where: $V$ - UPV $(\mathrm{km} / \mathrm{sec}) ; \rho-$ Bulk density $\left(\mathrm{kg} / \mathrm{m}^{3}\right)$; $g$ - Gravity acceleration $\left(9.81 \mathrm{~m} / \mathrm{sec}^{2}\right)$.

Results of the dynamic modulus of elasticity are shown in Table 3. The influence of the crumb rubber content on the $E_{D}$ of crumb rubber and steel fiber rubber concrete are seen in Figure 16. As shown in the same figure, the increase in the rubber content lead to decrease of the dynamic modulus for both ordinary and fiber reinforced concrete. The $E_{D}$ of SFC is 48.8 $\mathrm{GPa}$, inclusion of crumb rubber aggregate at $17.5 \%$, $20 \%, 22.5 \%$ and $25 \%$ ratios reduced this value by $29.3 \%, 30.5 \%, 42 \%$ and $47.3 \%$. The rate of reduction of $E_{D}$ was observed also similar to steel fiber crumb rubber concrete. The reduction in the dynamic modulus of elasticity of normal and steel fiber concrete is due

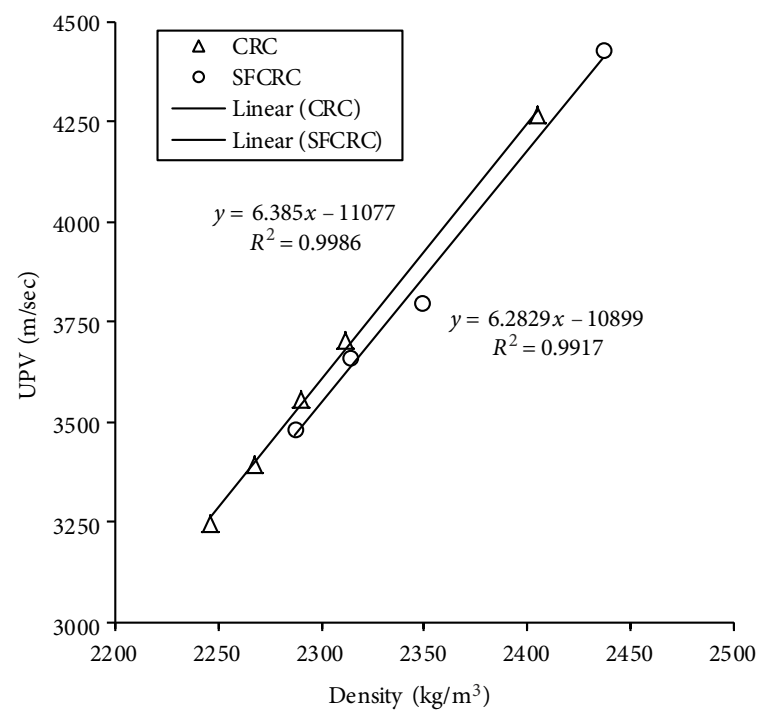

Fig. 15. The relationship between UPV and density for CRC and SFCRC

Table 3. Results of dynamic modulus of elasticity (GPa)

\begin{tabular}{|l|c|c|c|c|c|}
\hline $\begin{array}{l}\text { Type of } \\
\text { concrete }\end{array}$ & $0 \%$ & $17.5 \%$ & $20 \%$ & $22.5 \%$ & $25 \%$ \\
\hline Plain concrete & 44.6 & 32.3 & 29.5 & 26.6 & 24.1 \\
\hline $\begin{array}{l}\text { Steel fiber } \\
\text { concrete }\end{array}$ & 48.8 & 34.5 & 33.9 & 28.3 & 25.7 \\
\hline
\end{tabular}

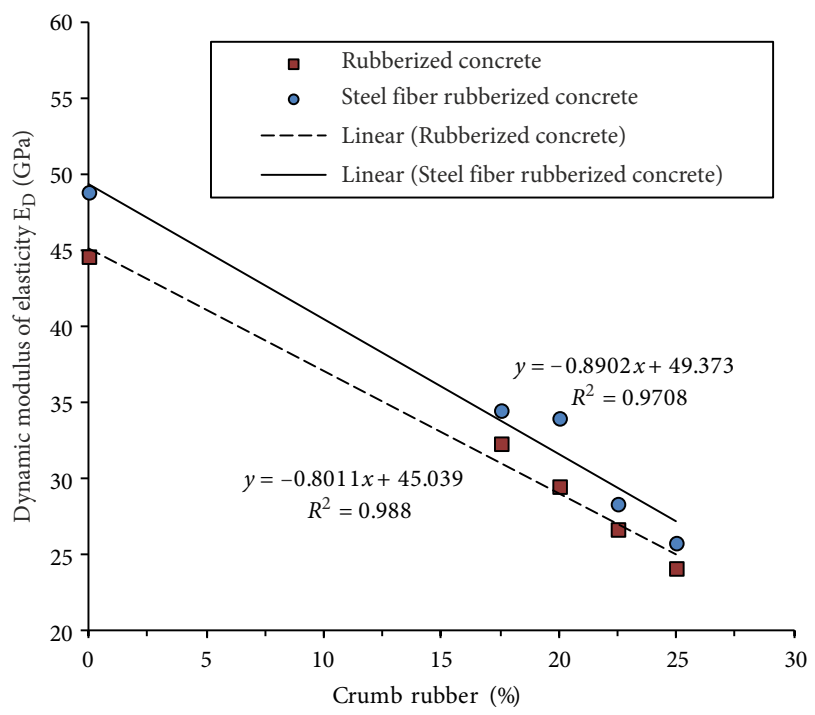

Fig. 16. Effet of crumb rubber content on dynamic modulus of elasticity $E_{D}$

to increased porosity of the mix caused by inclusion of crumb rubber aggregate which affects the compaction of the mixture (Uygunoğlu, Topçu 2010) and the low Young's' modulus of crumb rubber aggregates (Benazzouk et al. 2003). The reduction of the modulus of elasticity was observed by many authors when crumb 
rubber incorporated in different types of concrete (Khaloo et al. 2008; Uygunoğlu, Topçu 2010; Najim, Hall 2012; Zheng et al. 2008). A reduction in the values of the dynamic modulus of self-consolidated mortar was observed due to the inclusion of 50\% scrap tire rubber aggregate by $47.4 \%, 55.8 \%, 55.7 \%$ and $68.4 \%$ for various water to cement ratios $(0.40,0.43,0.47$ and 0.51), respectively (Uygunoğlu, Topçu 2010). Khaloo et al. (2008) reported a significant reduction of the ultra - pulse moduli when tire rubber aggregate content increased. This can be considered as a fundamental factor affecting the capacity of concrete to absorb more energy through the reduction of UPV. This type of concrete could be consequently used as a high vibration or shock energy absorber. This was approved also by the work conducted by (Benazzouk et al. 2006; Hernández-Olivares et al. 2007).

A correlation between $E_{D}$ and $E_{s}$ for all concrete mixes is shown in Figure 17, where a linear relationship is fitted between these parameters. However, these relations can be considered as an indicator for the relationship between static and mechanical properties of rubberized concrete.

\section{Conclusions}

The hardened mechanical properties of steel fiber rubberized concrete were investigated in this study. The following conclusions are presented based on the results obtained through the experimental work.

1. Partial replacement of fine aggregate using crumb rubber reduced the compressive strength of ordinary concrete mix. A similar rate of decrease was observed for steel fiberconcrete when crumb rubber was added. However, the results obtained for steel fiber rubber aggregate concrete were still higher than those for rubberized non fibrous concrete due to steel fiber inclusion. Reduction amplitude increased with crumb rubber content. The minimum results were obtained at 25\% replacement ratio.

2. Compared with the compressive strength results obtained in this study, a lower reduction in the results obtained for the modulus of elasticity was reported. The same reasons that might have led to the reduction in compressive strength could also be considered in this study because of the relationship between this strength and the elastic modulus under static compression test.

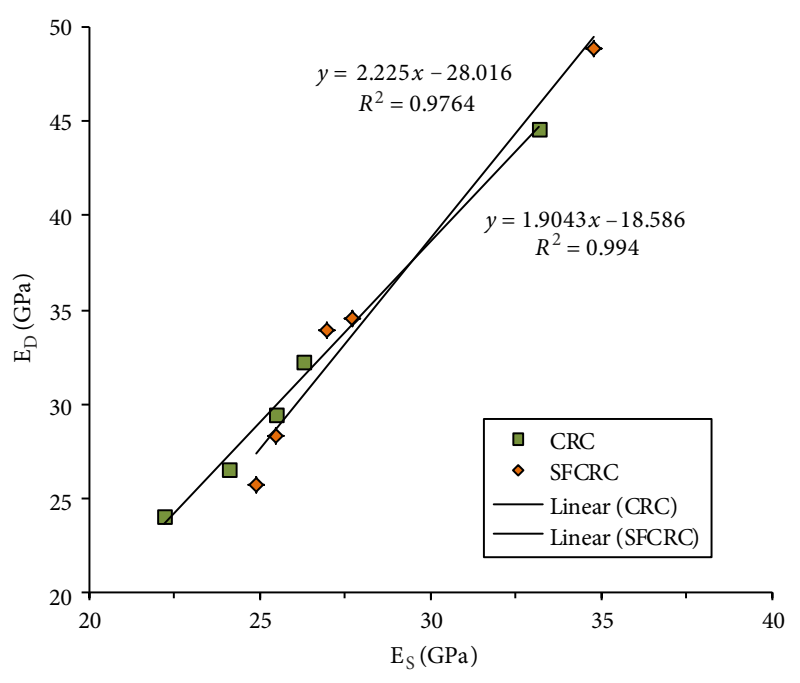

Fig. 17. The raltionship between static and dynamic moduli of CRC and SFCRC

3. Splitting tensile strength was reduced by the effect of crumb rubber. The reduction was between $23 \%$ and $32 \%$ for rubberized steel fiberconcrete.

4. Replacing the fine aggregate with recycled crumb rubber also presented a decline in the flexural strength of plain and steel fiber concrete. For all rubberized mixes values generally remained less than the flexural strength of the plain concrete.

5. The combined use of steel fibrous - rubber aggregate in concrete mixes has different influnce of the strain capacity of concrete. The maximum increase was $42 \%$ at $20 \%$ replacement ratios for non fibrous rubberized concrete, and $32 \%$ for steel fiberreinforced rubber aggregate concrete. Such results encourage the addition of recycled crumb rubber aggregate to steel fiber reinforced concrete to improve the toughness of steel fiber reinforced concrete while providing a lucrative means of solving an environmental problem caused by the disposal of waste tire in public areas.

6. UPV and dynamic modulus of elastcicity showed a decrease with increase oof crumb rubber aggragte inclusion into concrete. Thus, the tendency of steel fiber to absorb further energy can be enhenced by inclusion of crumb rubber aggregate due to increase porosity.

7. From the results mentioned above, the upper limit of crumb rubber content suggested to be $20 \%$ of the volume of fine aggregate due to the negative results obtained with $25 \%$ ratio. However, enhancement of the results obtained was also found in the strain ca- 
pacity values at this ratio. Thus, utilization of rubber aggregate with steel fiber in concrete is desired to enhance several properties of concrete, and further studies are warranted to confirm this.

\section{Acknowledgments}

The support provided by Universiti Sains Malaysia grant (Cluster for Polymer Composite: 1001/ $\mathrm{PKT} / 8640013)$ for funding this study is acknowledged.

\section{References}

Afshinnia, K.; Poursaee, A. 2015. The influence of waste crumb rubber in reducing the alkali-silica reaction in mortar bars, Journal of Building Engineering 4: 231-236. http://doi.org/10.1016/j.conbuildmat.2015.07.155

Al-Tayeb, M.; Bakar, B. A.; Akil, H.; Ismail, H. 2013. Performance of rubberized and hybrid rubberized concrete structures under static and impact load conditions, Experimental Mechanics 53(3): 377-384. https://doi.org/10.1007/s11340-012-9651-Z

Albano, C.; Camacho, N.; Reyes, J.; Feliu, J.; Hernández, M. 2005. Influence of scrap rubber addition to Portland I concrete composites: destructive and non-destructive testing, Composite Structures 71(3): 439-446.

https://doi.org/10.1016/j.compstruct.2005.09.037

ASTM C192. Standard practice for making and curing concrete test specimens in the laboratory. ASTM International, West Conshohocken, PA, United States, 2013.

ASTM C469. Standard test method for static modulus of elasticity and poisson's ratio of concrete in compression. ASTM International, West Conshohocken, PA, United States, 2014.

ASTM C496. Standard test method for splitting tensile strength of cylindrical concrete specimens. ASTM International, West Conshohocken, PA, United States, 2011.

ASTM C597. Standard test method for pulse velocity through concrete. ASTM International, West Conshohocken, PA, United States, 2009.

ASTM C78. Standard test method for flexural strength of concrete (using simple beam with third-point loading). ASTM International, West Conshohocken, PA, United States, 2010.

ASTM C1609. Standard test method for flexural performance of fiber-reinforced concrete (using beam with third-point loading). ASTM International, West Conshohocken, PA, United States, 2012.

Atahan, A. O.; Yucel, A. Ö. 2012. Crumb rubber in concrete: static and dynamic evaluation, Construction and Building Materials 36: 617-622.

https://doi.org/10.1016/j.conbuildmat.2012.04.068

Benazzouk, A.; Douzane, O.; Mezreb, K.; Queneudec, M. 2006. Physico-mechanical properties of aerated cement composites containing shredded rubber waste, Cement and Concrete Composites 28(7): 650-657.

https://doi.org/10.1016/j.cemconcomp.2006.05.006

Benazzouk, A.; Mezreb, K.; Doyen, G.; Goullieux, A.; Queneudec, M. 2003. Effect of rubber aggregates on the physico- mechanical behaviour of cement-rubber composites-influence of the alveolar texture of rubber aggregates, Cement and Concrete Composites 25(7): 711-720.

https://doi.org/10.1016/S0958-9465(02)00067-7

BS 1881:114. Methods for determination of density of hardened concrete. British Standards Institution, London, UK, 1983.

Carroll, J. C.; Helminger, N. 2016. Fresh and hardened properties of fiber-reinforced rubber concrete, Journal of Materials in Civil Engineering, 04016027.

https://doi.org/10.1061/(ASCE)MT.1943-5533.0001541

Fattuhi, N.; Clark, L. 1996. Cement-based materials containing shredded scrap truck tyre rubber, Construction and Building Materials 10(4): 229-236. https://doi.org/10.1016/0950-0618(96)00004-9

Ganjian, E.; Khorami, M.; Maghsoudi, A. A. 2009. Scrap-tyrerubber replacement for aggregate and filler in concrete, Construction and Building Materials 23(5): 1828-1836. https://doi.org/10.1016/j.conbuildmat.2008.09.020

Ghaly, A. M.; Cahill Iv, J. D. 2005. Correlation of strength, rubber content, and water to cement ratio in rubberized concrete, Canadian Journal of Civil Engineering 32(6): 10751081. https://doi.org/10.1139/105-063

Güneyisi, E.; Gesoğlu, M.; Özturan, T. 2004. Properties of rubberized concretes containing silica fume, Cement and Concrete Research 34(12): 2309-2317.

https://doi.org/10.1016/j.cemconres.2004.04.005

Guo, Y.; Zhang, J.; Chen, G.; Chen, G.; Xie, Z. 2014a. Fracture behaviors of a new steel fiber reinforced recycled aggregate concrete with crumb rubber, Construction and Building $\mathrm{Ma}$ terials 53: 32-39.

https://doi.org/10.1016/j.conbuildmat.2013.11.075

Guo, Y.-C.; Zhang, J.-H.; Chen, G.-M.; Xie, Z.-H. 2014b. Compressive behaviour of concrete structures incorporating recycled concrete aggregates, rubber crumb and reinforced with steel fibre, subjected to elevated temperatures, Journal of Cleaner Production (72): 193-203.

https://doi.org/10.1016/j.jclepro.2014.02.036

Hernández-Olivares, F.; Barluenga, G.; Parga-Landa, B.; Bollati, M.; Witoszek, B. 2007. Fatigue behaviour of recycled tyre rubber-filled concrete and its implications in the design of rigid pavements, Construction and Building Materials 21(10): 1918-1927.

https://doi.org/10.1016/j.conbuildmat.2006.06.030

Ho, A.; Turatsinze, A.; Vu, D.; Alexander, M.; Beushausen, H.; Dehn, F.; Moyo, P. 2008. On the potential of rubber aggregates obtained by grinding end-of-life tyres to improve the strain capacity of concrete, in M. G. Alexander, H. D. Beushausen, F. Dehn, P. Moyo (Eds.). Concrete repair, rehabilitation and retrofitting II. CRC Press, 123-129.

Ho, A. C.; Turatsinze, A.; Hameed, R.; Vu, D. C. 2012. Effects of rubber aggregates from grinded used tyres on the concrete resistance to cracking, Journal of Cleaner Production 23(1): 209-215. https://doi.org/10.1016/j.jclepro.2011.09.016

Hobbs, D. 1971. The dependence of the bulk modulus, Young's modulus, creep, shrinkage and thermal expansion of concrete upon aggregate volume concentration, Matériaux et Construction 4(2): 107-114. https://doi.org/10.1007/BF02473965 
Ibrahim, I. S.; Che Bakar, M. B. 2011. Effects on mechanical properties of industrialised steel fibres addition to normal weight concrete, Procedia Engineering 14(10): 2616-2626. https://doi.org/10.1016/j.proeng.2011.07.329

Issa, C. A.; Salem, G. 2013. Utilization of recycled crumb rubber as fine aggregates in concrete mix design, Construction and Building Materials 42: 48-52.

https://doi.org/10.1016/j.conbuildmat.2012.12.054

Khaloo, A. R.; Dehestani, M.; Rahmatabadi, P. 2008. Mechanical properties of concrete containing a high volume of tirerubber particles, Waste Management 28(12): 2472-2482. https://doi.org/10.1016/j.wasman.2008.01.015

Khatib, Z. K.; Bayomy, F. M. 1999. Rubberized Portland cement concrete, Journal of Materials in Civil Engineering 11(3): 206-213. https://doi.org/10.1061/(ASCE)0899-1561(1999)11:3(206)

Lee, J.-W.; Jang, Y.-I.; Park, W.-S.; Kim, S.-W. 2016. A study on mechanical properties of porous concrete using cementless binder, International Journal of Concrete Structures and Materials 10(4): 527-537. https://doi.org/10.1007/s40069-016-0166-3

Li, L.; Ruan, S.; Zeng, L. 2014. Mechanical properties and constitutive equations of concrete containing a low volume of tire rubber particles, Construction and Building Materials 70: 291-308. https://doi.org/10.1016/j.conbuildmat.2014.07.105

Liu, F.; Chen, G.; Li, L.; Guo, Y. 2012. Study of impact performance of rubber reinforced concrete, Construction and Building Materials 36: 604-616.

https://doi.org/10.1016/j.conbuildmat.2012.06.014

Liu, F.; Zheng, W.; Li, L.; Feng, W.; Ning, G. 2013. Mechanical and fatigue performance of rubber concrete, Construction and Building Materials 47: 711-719.

https://doi.org/10.1016/j.conbuildmat.2013.05.055

Marie, I. 2016. Zones of weakness of rubberized concrete behavior using the UPV, Journal of Cleaner Production 116: 217-222. https://doi.org/10.1016/j.jclepro.2015.12.096

Marques, A.; Correia, J.; De Brito, J. 2013. Post-fire residual mechanical properties of concrete made with recycled rubber aggregate, Fire Safety Journal 58: 49-57. https://doi.org/10.1016/j.firesaf.2013.02.002

Mohammed, B. S.; Azmi, N. J.; Abdullahi, M. 2011. Evaluation of rubbercrete based on ultrasonic pulse velocity and rebound hammer tests, Construction and Building Materials 25(3): 1388-1397.

https://doi.org/10.1016/j.conbuildmat.2010.09.004

Najim, K. B.; Hall, M. R. 2010. A review of the fresh/hardened properties and applications for plain- (PRC) and selfcompacting rubberised concrete (SCRC), Construction and Building Materials 24(11): 2043-2051. https://doi.org/10.1016/j.conbuildmat.2010.04.056

Najim, K. B.; Hall, M. R. 2012. Mechanical and dynamic properties of self-compacting crumb rubber modified concrete, Construction and Building Materials 27(1): 521-530. https://doi.org/10.1016/j.conbuildmat.2011.07.013

Nguyen, T. H.; Toumi, A.; Turatsinze, A. 2010. Mechanical properties of steel fibre reinforced and rubberised cementbased mortars, Materials \& Design 31(1): 641-647. https://doi.org/10.1016/j.matdes.2009.05.006
Noaman, A. T.; Abu Bakar, B. H.; Akil, H. M. 2016. Experimental investigation on compression toughness of rubberized steel fibre concrete, Construction and Building Materials 115: 163-170. https://doi.org/10.1016/j.conbuildmat.2016.04.022

Onuaguluchi, O.; Panesar, D. K. 2014. Hardened properties of concrete mixtures containing pre-coated crumb rubber and silica fume, Journal of Cleaner Production 82: 125-131. https://doi.org/10.1016/j.jclepro.2014.06.068

Park, Y.; Abolmaali, A.; Mohammadagha, M.; Lee, S. 2015. Structural performance of dry-cast rubberized concrete pipes with steel and synthetic fibers, Construction and Building Materials 77: 218-226. https://doi.org/10.1016/j.conbuildmat.2014.12.061

Rambo, D. A. S.; De Andrade Silva, F.; Toledo Filho, R. D. 2014. Effect of steel fiber hybridization on the fracture behavior of self-consolidating concretes, Cement and Concrete Composites 54: 100-109.

https://doi.org/10.1016/j.cemconcomp.2014.02.004

Reda Taha, M. M.; El-Dieb, A.; Abd El-Wahab, M.; Abdel-Hameed, M. 2008. Mechanical, fracture, and microstructural investigations of rubber concrete, Journal of Materials in Civil Engineering 20(10): 640-649.

https://doi.org/10.1061/(ASCE)0899-1561(2008)20:10(640)

Richardson, A.; Coventry, K.; Edmondson, V.; Dias, E. 2016. Crumb rubber used in concrete to provide freeze-thaw protection (optimal particle size), Journal of Cleaner Production 112: 599-606. https://doi.org/10.1016/j.jclepro.2015.08.028

Shen, W.; Shan, L.; Zhang, T.; Ma, H.; Cai, Z.; Shi, H. 2013. Investigation on polymer-rubber aggregate modified porous concrete, Construction and Building Materials 38: 667-674. https://doi.org/10.1016/j.conbuildmat.2012.09.006

Siddique, R.; Naik, T. R. 2004. Properties of concrete containing scrap-tire rubber-an overview, Waste Management 24(6): 563-569. https://doi.org/10.1016/j.wasman.2004.01.006

Solis-Carcaño, R.; Moreno, E. I. 2008. Evaluation of concrete made with crushed limestone aggregate based on ultrasonic pulse velocity, Construction and Building Materials 22(6): 1225-1231.

https://doi.org/10.1016/j.conbuildmat.2007.01.014

Sukontasukkul, P. 2009. Use of crumb rubber to improve thermal and sound properties of pre-cast concrete panel, Construction and Building Materials 23(2): 1084-1092. https://doi.org/10.1016/j.conbuildmat.2008.05.021

Thomas, J.; Ramaswamy, A. 2007. Mechanical properties of steel fiber-reinforced concrete, Journal of Materials in Civil Engineering 19(5): 385-392. https://doi.org/10.1061/(ASCE)0899-1561(2007)19:5(385)

Topçu, I. B.; Avcular, N. 1997. Collision behaviours of rubberized concrete, Cement and Concrete Research 27(2): 18931898. https://doi.org/10.1016/S0008-8846(97)00204-4

Turatsinze, A.; Granju, J. L.; Bonnet, S. 2006. Positive synergy between steel-fibres and rubber aggregates: Effect on the resistance of cement-based mortars to shrinkage cracking, Cement and Concrete Research 36(9): 1692-1697. https://doi.org/10.1016/j.cemconres.2006.02.019

Uygunoğlu, T.; Topçu, İ. B. 2010. The role of scrap rubber particles on the drying shrinkage and mechanical properties of self-consolidating mortars, Construction and Building Materials 24(7): 1141-1150.

https://doi.org/10.1016/j.conbuildmat.2009.12.027 
Yazıcı, S.; Inan, G.; Tabak, V. 2007. Effect of aspect ratio and volume fraction of steel fiber on the mechanical properties of SFRC, Construction and Building Materials 21(6): 12501253. https://doi.org/10.1016/j.conbuildmat.2006.05.025

Youssf, O.; Elgawady, M. A.; Mills, J. E.; Ma, X. 2014. An experimental investigation of crumb rubber concrete confined by fibre reinforced polymer tubes, Construction and Building Materials 53: 522-532.

https://doi.org/10.1016/j.conbuildmat.2013.12.007
Zheng, L.; Huo, X. S.; Yuan, Y. 2008. Strength, modulus of elasticity, and brittleness index of rubberized concrete, Journal of Materials in Civil Engineering 20(11): 692-699. https://doi.org/10.1061/(ASCE)0899-1561(2008)20:11(692)

Ahmed Tareq NOAMAN is a lecturer at Department of Dams and Water Resources Engineering, University of Anbar. Recently, he awarded his PhD from Universiti Sains Malaysia in construction technology. His research interests including green concrete, toughness and impact energy of structural members, and finite element analysis.

Badorul Hisham ABU BAKAR. He obtained the PhD from Leeds University, UK in the year 1998. He is currently a full Professor in School of Civil Engineering, Universiti Sains Malaysia. He published more than 60 papers in international journals. Currently, he is interesting on the behavior of ultra high strength concrete and structural properties of rubberized concrete.

Hazizan MD. AKIL is a Professor of Polymer Composites, Universiti Sains Malaysia. He obtained his PhD in Composites Materials from the University of Liverpool, UK, in 2002. He joined Universiti Sains Malaysia as a lecturer in the School of Materials and Mineral Resources Engineering. His high quality research has been further supported by more than 200 international journal publications, total citations of 2804 times and an h-index of 26. 